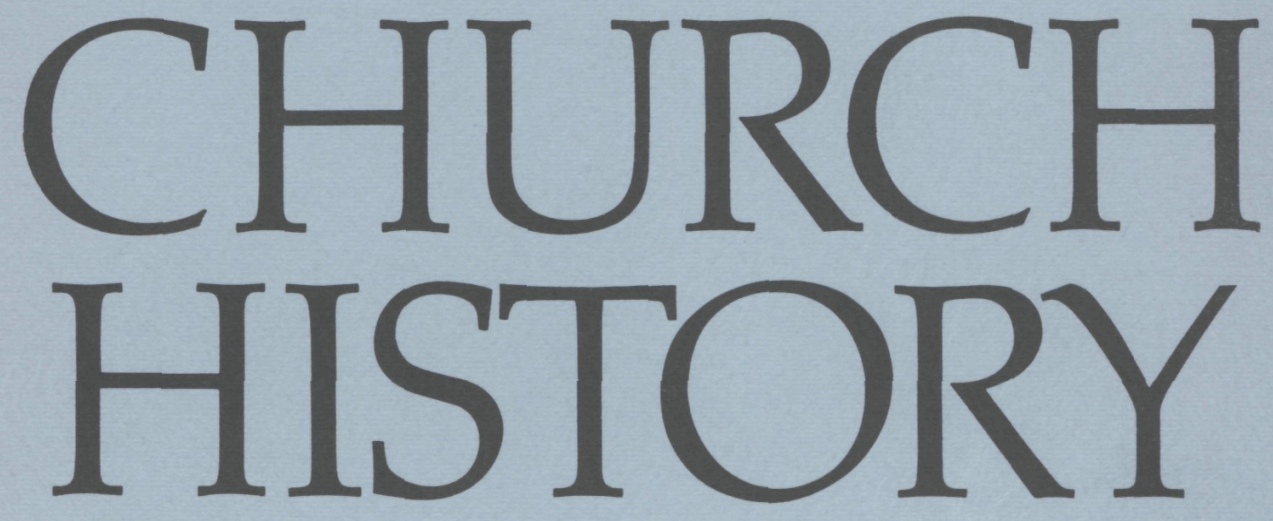

AMERICAN SOCIETY OF CHURCH HISTORY, SEPTEMBER, 1987 https://doi.org/10.1017/S0009640700057930 Published online by Cambridge University Press 


\title{
THE AMERICAN SOCIETY OF CHURCH HISTORY
}

\author{
PRESIDENT \\ JaY P. Dolan, University of Notre Dame \\ PRESIDENT-ELECT \\ William J. Courtenay, University of Wisconsin \\ SECRETARY-TREASURER \\ William B. Miller, Wallingford, PA \\ ASSISTANT SECRETARY \\ Stuart C. Henry, The Divinity School, Duke University \\ EDITORS
}

Jerald C. BRAUER ROBERT M. GRANT MARTIN E. MARTY
The Divinity School, University of Chicago

\section{MEMBERS OF THE COUNCIL}

Class of 1987

Catherine L. Albanese

GREGORY T. ARMSTRONG

DANIEL W. HOWE

JAN SHIPPS

LEONARD I. SWEET

Class of 1988

TiMOTHY GEORGE

E. GLENN HINSON

KATHRYN L. JOHNSON

Kathleen E. MaVey

Frederick V. Mills, SR.

Class of 1989

Robert C. GRegG

KenNETH G. HAGeN

SUSAN E. SGHREINER

DENNIS N. VOSKUIL

GRANT WACKER

The Society was founded in 1888 by Philip Schaff, was reorganized in 1906, and was incorporated by act of the Legislature of the State of New York in 1916. 
Vol. $56 \quad$ September $1987 \quad$ No. 3

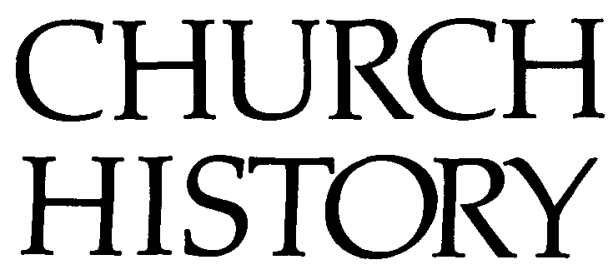

Published quarterly by

THE AMERICAN SOCIETY OF CHURCH HISTORY

() 1987, The American Society of Church History 


\section{CHURCH HISTORY EDITORS}

$\left.\begin{array}{l}\text { Jerald C. Brauer } \\ \text { Robert M. Grant } \\ \text { Martin E. Marty }\end{array}\right\}$

\section{The Divinity School, University of Chicago}

\section{with the cooperation of}

Jane D. Douglass, Princeton Theological Seminary

Mark U. Edwards, JR., Purdue University

ROBERT T. HANDY, Union Theological Seminary

Bernard MaGinn, The Divinity School, University of Chicago

Richard A. NORRIS, Union Theological Seminary

Albert J. Raboteau, Princeton University

JOHN F. WILSON, Princeton University

\section{assistants to the editors \\ TERRY E. SPARKES \\ ELLEN L. BABINSKY}

Church History is published quarterly in March, June, September, and December by the American Society of Church History. Subscription prices are $\$ 25.00$ a year (students with recommendation of professor and persons having been society members for five years and now retired from professional life- $\$ 12.50$ ); $\$ 7.00$ for single issues; $\$ 4.00$ per year extra should be added for foreign countries. Please make all remittances payable to the American Society of Church History. Subscription applications, renewals, changes of address, claims for missing numbers, and orders for single copies of current or back issues should be sent to William B. Miller, 305 E. Country Club Lane, Wallingford, PA 19086. Claims for missing numbers will be honored without charge if made within two months following the regular month of publication.

Microfilm reproductions of The American Society of Church History Papers, series I and II, and of Church History, vols. 1-17 (1932-48), are available from the ATLA Preservation Board. Orders for these reproductions as well as inquiries about microfilm portions and xerox copies should be sent to P.O. Box 111, Princeton, New Jersey 08540.

Microfilm reproductions of Church History starting with vol. 18 (1949) are available to subscribers and members of the society from University Microfilms, 300 N. Zeeb Road, Ann Arbor, Michigan 48106. Church History is indexed in Religion Index One: Periodicals, published by the American Theological Library Association, Chicago, available online in the ATLA Religion Database through BRS Information Technologies (Latham, New York) and DIALOG Information Services (Palo Alto, California).

The following indexes are available from the treasurer, William B. Miller, at the address given above: Papers and vols. 1-30 (1932-1961), \$5.50; vols. 31-39 (1962-1970), \$5.50; vols. 40-49 (1971-1980), $\$ 10.00$ ( $\$ 8.00$ for active, individual members of the Society). Add $\$ 1.00$ postage charges. Book reviews are indexed or abstracted in Book Review Index, Historical Abstracts, and America: History and Life.

Manuscripts and books for review should be sent to Church History, Swift Hall, 1025 E. 58th St., Chicago, Illinois 60637. Manuscripts submitted for consideration must be typed double-spaced on sturdy paper; footnotes must be typed double-spaced on separate pages following the text. Manuscripts exceeding twenty-five pages in length (including footnotes) cannot be considered. Please submit two copies of the manuscript (no carbons) and include correct return postage.

Advertising orders and requests for permission to quote should be addressed to the editorial office in Chicago.

Church History is printed by Science Press, Ephrata, Pennsylvania. Second-class postage said at Wallingford, Pennsylvania and additional mailing offices. 


\section{CONTENTS}

303 Justin Martyr and the Restoration of Philosophy

ARTHUR J. DROGE

320 Popular and Monastic Pastoral Issues in the Later Middle Ages DENNIS D. MARTIN

333 Elizabeth Bowes and John Knox: A Woman and Reformation Theology
A. Daniel Frankforter

348 The Ritual of Happy Dying among Early American Methodists

\section{A. GREGORY SCHNEIDER}

364 “Must God Go Fascist?": English Catholic Opinion and the Spanish Civil War JAMES FLINT, O.S.B.

\section{Book Reviews}

Hanson, Paul D., The People Called: The Growth of Community

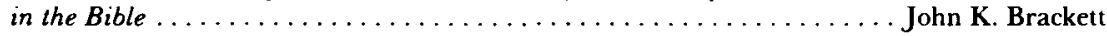

Snyder, Graydon, Ante Pacem: Archaeological Evidence of Church Life before Constantine . . . . . . . . . . . . . . . . . . . . . Paul Corby Finney

Torjesen, Karen Jo, Hermeneutical Procedure and Theological Method in Origen's Exegesis . . . . . . . . . . . . . . . . . . Allan E. Johnson

Clarke, G. W., trans., The Letters of St. Cyprian of Carthage, vols.

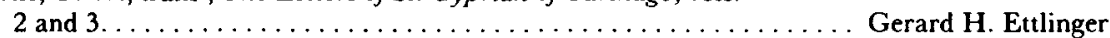

Fox, Robin Lane, Pagans and Christians . . . . . . . . . . . . . Robert M. Grant

Goehring, James E., The Letter of Ammon and Pachomian

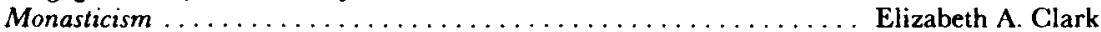

Meyer, Robert T., ed., Palladius: Dialogue on the Life of Saint

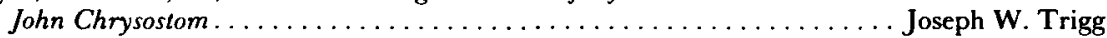

Taft, Robert, The Liturgy of the Hours in East and West: The Origins of the Divine Office and Its Meaning for Today . . . . . . . Clarence C. Menard

Pontal, Odette, Die Synoden im Merowingerreich . . . . . . . . . . . . . Harry Rosenberg

Enright, Michael J., Iona, Tara, and Soissons: The Origin of the Royal Anointing Ritual . . . . . . . . . . . . . . . . . Susan A. Keefe

Lynch, Joseph H. Godparents and Kinship in Early Medieval

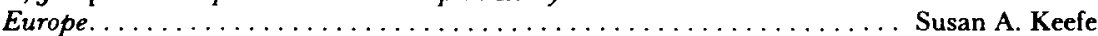

Vollrath, Hanna, Die Synoden Englands bis $1066 \ldots \ldots \ldots \ldots \ldots$. . . . . Richard W. Pfaff

Bredero, Adriaan H., Cluny et Citeaux au douzieme siècle: L'Histoire d'une controverse monastique . . . . . . . . . . E. Randolph Daniel Jordan, Mark D., Ordering Wisdom: The Hierarchy of

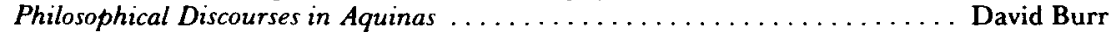

Tobin, Frank, Meister Eckhart: Thought and Language . . . . . . . . . . . David Burr Murray, Alexander, Reason and Society in the Middle Ages . . . . . . . . John R. Sommerfeldt Walsh, Katherine, and Wood, Diana, eds., The Bible in the Medieval World: Essays in Memory of Beryl Smalley. . . . . . . . . . Donald J. Grimes Stephens, W. P., The Theology of Huldrych Zwingli . . . . . . . . . . . J. Wayne Baker 
Janz, Denis, Luther and Late Medieval Thomism: A Study in Theological Anthropology.

Jeannine E. Olson

Kittelson, James M., Luther the Reformer: The Story of the Man and $H$ is Career . . ............................ Heiko A. Oberman

Strauss, Gerald, Law, Resistance, and the State: The Opposition to

Roman Law in Reformation Germany. . . . . . . . . . . . . . Gottfried G. Krodel

Lancashire, Douglas, and Kuo-chen, Peter Hu, trans., Malteo Ricci: The True Meaning of the Lord of Heaven (T'ien-chu

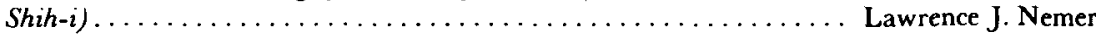

Eire, Carlos M. N., War Against the Idols: The Reformation of Worship from Erasmus to Calvin . . . . . . . . . . . . . . . . . Lowell H. Zuck

Stauffenberger, Roger, Église et société: Genève au XVIIe Siècle . . . . . . . . W. Fred Graham Lupinin, Nickolas, Religious Revolt in the XVIIth Century: The Schism of the Russian Church . . . . . . . . . . . . . . Charles A. Frazee

Hirst, Derek, Authority and Conflict in England, 1603-1658 . . . . . . . . . Leo F. Solt

Davies, Horton, Like Angels From a Cloud: The English

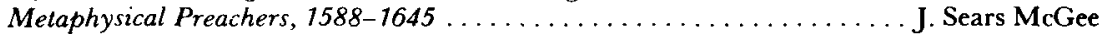

Reedy, Gerard, The Bible and Reason: Anglicans and Scripture in Late Seventeenth-Century England ................. . FitzSimons Allison

Brown, Raymond, The English Baptists of the 18th Century. . . . . . . . . . . . Sam E. Hester

Whaley, Joachim, Religious Toleration and Social Change in Hamburg, $1529-7879 \ldots \ldots \ldots \ldots \ldots \ldots \ldots$ Virginia DeMarce

Martin, B. Edmon, All We Wart is Make Us Free: La Amistad and the Reform Abolitionists.

Milton C. Sernett

Fuller, Robert C., Americans and the Unconscious. . . . . . . . . . Catherine L. Albanese

O'Dwyer, Margaret M., The Papacy in the Age of Napoleon and the Restoration: Pius VII, 1800-1823 ................... C. T. McIntire

McDannell, Colleen, The Christian Home in Victorian America, $1840-1900 \ldots \ldots \ldots \ldots \ldots \ldots \ldots \ldots \ldots \ldots \ldots \ldots \ldots \ldots \ldots \ldots$. Gregory Schneider

Helmstadter, Richard J., and Phillips, Paul T., eds., Religion in Victorian Society: A Sourcebook of Documents.

William L. Sachs

Bowen, Desmond, Paul Cardinal Cullen and the Shaping of Modern Irish Catholicism. . . . . . . . . . . . . . . . . . . . Brian P. Clarke

Arnal, Oscar L., Ambivalent Alliance: The Catholic Church and the Action Française, 1899-1939

Nadia M. Lahutsky

Cowling, Maurice, Religion and Public Doctrine in Modern England. Vol. 2, Assaults ...................... Dale A. Johnson

Christensen, Torben, and Hutchison, William R., eds., Missionary Ideologies in the Imperialist Era, 1880-1920

E. Theodore Bachmann

Orsi, Robert Anthony, The Madonna of 115th Street: Faith and Community in Italian Harlem, 1880-1950

Peter W. Williams

Mainwaring, Scott, The Catholic Church and Politics in Brazil, 1916-1985.

Miles, Margaret R., Image as Insight: Visual Understanding in Western Christianity and Secular Culture . . . . . . . . . . John Dillenberger

Mabee, Charles, Reimagining America: $A$ Theological Critique of the American Mythos and Biblical Hermeneutics . . . . . . . . . . Peter W. Williams

Davis, Moshe, ed., With Eyes Toward Zion, Volume II: Themes and Sources in the Archives of the United States, Great Britain, Turkey and Israel

Washington, Joseph R., Jr., ed., Jews in Black Perspective: $A$ Dialogue . . . . . . . . . . . . . . . . . . . Ronald C. White, Jr.

Au, William A., The Cross, The Flag and The Bomb: American Catholics Debate War and Peace, 1960-1983 Anthony W. Novitsky

\section{Reprints and Books Received}

\section{Society Notices}

